\title{
AN ANALYSIS ON THE MEASURES TAKEN BY FINANCE MINISTRY TO UPLIFT THE INDIAN ECONOMY DURING COVID-19
}

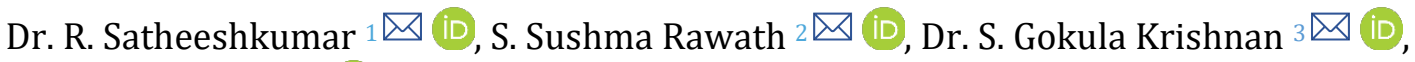 \\ Ms. Niveditha. J 4 (D)
}

\begin{abstract}
${ }^{1}$ Professor, Department of M.B.A, Surana College, Kengeri Campus, KST, Bangalore, Karnataka-560060. Phone: 9487271346

2 Assistant Professor, Department of M.B.A, Surana College, Kengeri Campus, KST, Bangalore, Karnataka560060. Phone: 9482413278

${ }_{3}^{3}$ Associate Professor, Department of Management Studies, Acharya Institute of Technology, Bangalore - 56107. Phone: 9489766214

${ }^{4}$ Business Development Executive, Juego Studio Pvt. Ltd, Bangalore. Phone: 8553951509
\end{abstract}

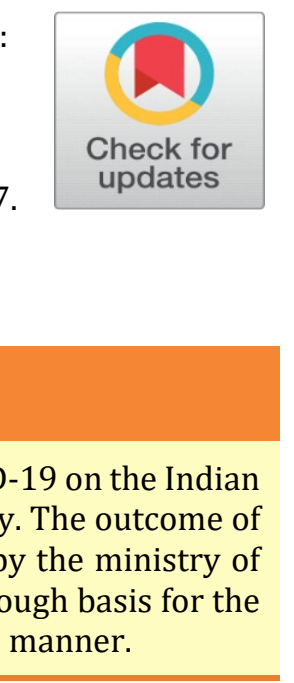

Received 5 July 2021

Accepted 20 August 2021

Published 31 August 2021

\section{CorrespondingAuthor}

Dr. S. Gokula Krishnan,

prof.gokulakrishnan@gmail.com

DOI

10.29121/granthaalayah.v9.i8.2021. 4199

Funding: This research received no specific grant from any funding agency in the public, commercial, or not-for-profit sectors.

Copyright: (C) 2021 The Author(s). This is an open access article distributed under the terms of the Creative Commons Attribution License, which permits unrestricted use, distribution, and reproduction in any medium, provided the original author and source are credited.

\section{ABSTRACT}

This article will throw the light on impact of the global pandemic COVID-19 on the Indian economy including its detailed impact on all the sectors of the economy. The outcome of the study will also highlight the impact of the measures undertaken by the ministry of finance to tackle situations more rationally and set an example and enough basis for the policymakers to make policies for handling the situation in an effective manner.

Keywords: Covid-19, Global Pandemic, Economy, Policies, Financial Measures

\section{INTRODUCTION}

Coronavirus disease 2019 (COVID-19) is an infectious disease caused by severe acute respiratory syndrome coronavirus 2 (SARS-CoV-2). It was first identified in Wuhan, Hubei, China, in December 2019 and has become a global pandemic. India is in unlock phase after 5 lockdowns which was announced by Prime Minister Mr. Narendra Modi. India is now going through unlock 2.0 with the same regulations as of unlock 1.0 which came into effect from June 2020. It is a major step taken by the central Government to reduce the spread of Corona virus as it is an infectious disease which spreads from person to person through small droplets from the nose or mouth from the person with COVID- 19 coughs or exhales to the other person.

The economic activities like manufacturing, production, trade, business, services, agriculture, small and medium enterprises, film and music industry, automobile, arts and commerce etc. have been affected severely by the outburst of COVID-19. The private sector, the public sector, as well as the multi-national companies have also stopped their economic activities owing to COVID-19. This has severely affected the GDP and National Income of the country. It resulted as economic downfall in the country. It is important for the policy makers of the country to assess the financial crisis brought about by the pandemic and the methods and techniques to fight the same so that such crisis should not arise in the future. It gives the policy makers and leaders of the country to tackle the situation more rationally. 


\section{REVIEW OF LITERATURE}

Sengupta (2020), in their paper titled, "Covid-19: Impact on the Indian Economy", have analyzed the Indian economy in the pre-Covid-19 period and have assessed the impact of the shock on various sectors of the economy due to ongoing covid19. They have also discussed the policies which have been announced by the Indian Government as a way of improving the present economic condition.

Dr. M. Murugeswari (2020), in her article titled "Impact of Coronavirus (Covid19) on Indian Economy: An Overview", presents an outline of the impact of coronavirus on Indian economy. Various industries and businesses are severely affected by the crisis. The extended lockdown has left a deep imprint on Indian economy.

Raut (2020), have analyzed the impact of covid19 on different sectors of the Indian economy. As stated in the paper, "A Study of Indian Economy during Covid19 Pandemic", all the financial agencies have been downgraded. The Indian economy is expected to lose over Rs.32, 000 Crores every day during the first 21 days of lockdown. There is direct impact on demand and supply of goods. The service sector is also facing reduced cash flow due to slow economic activities.

Goyal (2020), “Post Covid-19: Recovering and Sustaining India's Growth” - This research article discusses virtuous growth cycles in India in the past years and argues that the post Covid- 19 macro-financial package is an opportunity to trigger another such growth cycle by raising marginal propensities to spend above those to save. The study found that a limited, well targeted and transient stimulus would avoid the present reduced cashflow while preventing illiquidity becoming insolvency, relieving persistent financial stress, and creating a virtuous growth cycle.

Selvan (2020) article titled "Impact of COVID-19 on Indian Banking Sector" deals about the impact of COVID 19 on the Indian Banking Sector. The paper showcases those financial markets have been facing high volatility due to panic selloff resulting into destruction of equity markets.

\section{RESEARCH DESIGN AND METHODS}

\subsection{STATEMENT OF THE PROBLEM}

Since the whole of 1.3 billion population stayed at home, there were neither production activities nor trade or businesses which were the main source of income for majority of the population. Many Indians as well as NRIs lost jobs and took refuge in India. This has put the people's life at risk and they have been forced to seek a relief measure from the Government. Since one thirds of the population are in poverty and around 50 million people are under BPL, the finance minister Shree Nirmala Sitharaman announced the 20-lakh crore relief package covering several aspects of the dearth of the poor as well as measures to uplift the falling economy. Thus, the present study requires the extensive examination of the measures taken by the finance minister to improve the economic situation during this pandemic scenario.

\subsection{OBJECTIVES OF THE STUDY}

1) To assess the Indian economy during the covid-19 pandemic period

2) To analyze the various steps and the relief measures taken by finance ministry, GOI during COVID-19 
3) To evaluate the impact of the measures undertaken by the ministry of finance to tackle situations more rationally.

\subsection{SOURCES OF DATA}

The data have been collected through secondary source. The data have been collected through newspaper and web articles, related research articles, blogs, television broadcasts and the press releases by the Finance Ministry and GOI. On a continuous basis from the time of covid-19 inception in India.

\subsection{PLAN OF ANALYSIS}

The data collected through these sources will be analyzed using various tools based on the effectiveness of the relief measures taken by the Finance Ministry, GOI in lifting the Indian economy and by comparing the current economic condition with that of, which existed prior to covid-19 period. The analyzed data have been presented in a descriptive manner with the graphs and charts and interpretation have been given for each of the relief measures.

\subsection{LIMITATIONS OF THE STUDY}

1) Being it is secondary data-based analysis, it has its own limitation of information reliability.

2) Researcher had the time constraints to capture the relevant information from different source on a continual basis.

\section{DATA ANALYSIS AND INTERPRETATION}

The several relief measures taken by the Finance Ministry, GOI have been discussed below in detail.

- On 26 March, the Union Finance Minister, Shri Nirmala Sitharaman announced a ₹170,000 crore (US $\$ 24$ billion) stimulus package called the PMGKP- Prime Minister Garib Kalyan Package, to help those who have been affected by the lockdown. The breakup of PMGKP are as follows:

1) Rs 2000 for farmers, as the first instalment of the PM - Kisan Fund will be given at the beginning of the financial year (April), which will benefit 8.69 crore farmers immediately

2) Wage hike in MGNREGA from Rs182 to 202 will result in 2000Rs extra per worker which will benefit five crore families in the rural areas

3) ₹1,000 has been provided for poor senior citizens, widows and the disabled for the first three months to fight any difficulties regarding their health which will benefit 3 crore people (poor senior citizens, widows and the disabled)

4) An ex-gratia amount of ₹500 each will be given to 20 crore women with Jan Dhan accounts to ease them in their household endeavors.

5) LPG cylinders have been provided to 8 crore poor families including women in rural areas for the first three months for free under the Ujjwal scheme.

6) Amount of Rs10 lakhs collateral free loans being doubled for women SHGs i.e., they can now avail Rs 20 lakh as collateral free loans, which will benefit seven crore households through the 63 lakh SHGs.

7) Govt of India will pay full EPF contribution by both employer and employee, (12\% each totaled to $24 \%)$ for 3 months for those 
organizations who have upto 100 employees and $90 \%$ of them who are earning less than Rs 15,000 per month. This comes under the PM Garib Kalyan yojana

8) The EPFO regulations will be amended to allow non-refundable advance of $75 \%$ of the amount standing to the credit of a member or three months of wages. This will benefit 80 lakh employees in the organized sector.

9) Expanded insurance for health care workers and the date of premium payments also extended up to 3 months.

10) Establishing a fund to help construction workers affected by the lockdown.

Around 41 crore poor people received financial assistance of Rs 52,608 crore altogether under the PMGKP.

- Another set of measures have been taken by the Govt of India to contain the fallout of the economy and make India economically strong in the upcoming years.

On May 13, Hon'ble Prime Minister, Mr.Narendra Modi announced that a new stimulus package called the Atma Nirbhar Bharat Package (Self-Reliant India,) package of 20 lakh crores ( $\$ 266$ billion) will be released by the Finance Minister, Shri Nirmala Sitharaman, as fiscal and monetary measures to support the economy. He has also outlined the five pillars of Atma Nirbhar Bharat - in terms of Economy, Infrastructure, System, Vibrant Demography and Demand. The package would be released in five separate parts, some of which include general reform measures.

\subsection{FIRST TRANCHE - ₹ 5, 94,550 CRORES}

The first set of relief measures was announced by Nirmala Sitharaman on May 13th whose main focus was on the Indian economy's backbone - MSMEs that employ around 11 crore people and have a GDP share of approximately 29 per cent. The first set of announcements was aimed to eliminate the distress caused by the pandemic in the MSME sector. Out of the sixteen announcements, six were dedicated to the MSME segment to infuse liquidity. The other announcements include, extending various tax filing deadlines, reduction in payroll taxes etc.

Table 1 A brief note of the First Tranche of the Atma Nirbhar Package

\begin{tabular}{|c|c|c|}
\hline Sl. No & Particulars & $\begin{array}{c}\text { Amount (in Rupees) and } \\
\text { brief }\end{array}$ \\
\hline 1. & $\begin{array}{c}\text { Emergency Working Capital } \\
\text { Facility for Businesses, } \\
\text { includingMSMEs }\end{array}$ & $\begin{array}{c}\text { ₹ } 3 \text { lakh crore } \\
\text { Emergency working capital of } 20 \% \text { of the } \\
\text { outstanding credit of businesses at the endof } \\
\text { February 2020, will be provided in the form } \\
\text { of a Term Loan at a concessional rate of } \\
\text { interest. }\end{array}$ \\
\hline 2. & $\begin{array}{l}\text { Additional Debt for } \\
\text { Stressed MSMEs }\end{array}$ & $\begin{array}{l}\qquad ₹ 20,000 \text { crore } \\
\text { Banks are required to finance subordinate } \\
\text { debt for twolakh MSMEs which are either } \\
\text { NPA or are stressed. }\end{array}$ \\
\hline
\end{tabular}


Dr. R. Satheesh Kumar, S. Sushma Rawath, Dr. S. Gokula Krishnan, and Ms. Niveditha. J

3. Equity injection throughMSME

Fund of Funds

4.

New definition of MSME
Rs 50,000 crores

The Fund of Funds will mobilize an equity of aboutR50,000 crores for MSMEs

MSME definition will be revised by increasing theminimum Investment limit and adding a turnover criterion.

5. Global tenders disallowed

Move is aimed at protecting MSMEs from the up to ₹200crore unfaircompetition from foreign entities.

6. Other interventions for MSMEs

E-market linkage is provided.

Pending dues from the Government or government-owned companies will be cleared in the next 45 days.

7. Employees ProvidentFund

Rs 2500 crores

This move is for the salaried and

organized staff which will benefit 72.22 lakh employees.

8. EPF Contribution to be reduced

SPF contribution by both employer and employee isreduced to $10 \%$ each from the existing $12 \%$ each for 3 months

9.

$$
\text { Special Liquidity }
$$

Rs 30,000 crores

Scheme for NBFC/HFC/MFIs

Made available by RBI to commercial banks to fundNBFCs and other institutions through investment in corporate bonds

10. Partial credit guarantee

Scheme 2.0

Rs 45,000 crores

This is for liabilities of NBFCs/MFIs etc.

11. Liquidity Injection for Rs 90,000 crore

DISCOMS

To be utilized by DISCOMS to pay their pendingdues to Generation companies and Transmissioncompanies

12. Relief to Contractors

All agencies like Railways etc. will get an extension of 6 months to complete their contractual obligations

\begin{tabular}{|c|c|c|}
\hline 13. & Relief to Real Estate & $\begin{array}{l}\text { The registration and completion date } \\
\text { for the registered projects shall be } \\
\text { extended to } 6 \text { months. }\end{array}$ \\
\hline 14. & Tax Relief to Businesses & $\begin{array}{l}\text { The pending income tax refunds shall be } \\
\text { disbursed immediately. }\end{array}$ \\
\hline 15. & Tax-related measures & $\begin{array}{l}\text { Reduction in rates of TCS and TDS will } \\
\text { provideliquidity of Rs } 50,000 \text { Crore. }\end{array}$ \\
\hline 16. & Income Tax Returns Filing & The date of filing of Income Tax Returns for \\
\hline
\end{tabular}




\section{Interpretation}

1) The relief measures for the MSMEs will destress the sector by infusing liquidity of about three lakh crores. This will help the MSMEs to borrow loans from the bank without collateral security.

2) Equity infusion of Rs 50,000 crores through MSME Fund of Funds will help in expanding MSME size as well as activity. In order to do this, the Govt will create a Fund of Funds with an amount of Rs 10,000 crore which will provide equity financial support for MSMEs.

3) The new definition of the MSMEs so announced by changing their investment limits will benefit the MSMEs to avail loans at cheaper rates while still being under the term MSMEs.

4) Disallowing of global tenders up to 200 crores from foreign corporations will protect MSMEs from the unfair and unhealthy competition from foreign entities.

5) The EPF contribution by both employer and employee, (12\% each totaled to $24 \%$ ) for 3 months which will be provided to salaried staff as compensation to loss of pay during the lockdowns, thus creating more liquidity in the country by ensuring more disposable income in the hands of individuals.

6) The relief to real estate and construction contractors will benefit the real estate builders as they now cannot be sued for non-completion of the project within time.

7) The Government has extended the date of income tax returns filing to November 30 presuming that by that time, the virus would have been contained to such an extent that some of the economic activities could be resumed so that the salaried folk are able to file tax returns.

\subsection{SECOND TRANCHE - ₹ 3, 10,000 CRORES}

Shri Nirmala Sitharaman's second tranche of measures catered to migrant workers and street vendors. It is a 'One Nation One Ration Card' to allow migrant workers to buy ration from any depot in the country. The Minister has introduced a special credit of Rs 5,000 crore to support 50 lakh street vendors who will have access to initial working capital of Rs 10,000. The Minister also said that almost Rs 2 lakh crore will be given to farmers via Kisan credit cards while 2.5 crore farmers could get institutional credit at a concessional rate. The Government has allowed states to fund the food and shelter facilities to migrant workers from the disaster response fund and it would cost Rs 11,000 crore to the centre.

Table 2 Table representing the Second Tranche of the package

\begin{tabular}{|c|c|c|}
\hline Sl. No & Particulars & Amount (in Rupees) and brief \\
\hline 1. & Migrant workers & $\begin{array}{l}\text { Free food grains and affordable housing for } \\
\text { migrantworkers/urban poor to ease their } \\
\text { livelihood }\end{array}$ \\
\hline
\end{tabular}


2.

\begin{tabular}{|c|c|c|}
\hline 2. & Farmers & $\begin{array}{l}\text { Extension of interest subvention and Rs 30,000 } \\
\text { crores additional emergency working capital } \\
\text { fundingthrough NABARD which will support } \\
\text { around three crore farmers }\end{array}$ \\
\hline 3. & Mudra Shishu loan & $\begin{array}{l}\text { Interest subvention of } 2 \% \text { for Mudra Shishu } \\
\text { loanholders. }\end{array}$ \\
\hline 4. & Street Vendors & $\begin{array}{l}\text { Rs } 50,000 \text { crore } \\
\text { Special scheme to ease credit facilities to } \\
\text { streetvendors }\end{array}$ \\
\hline 5. & $\begin{array}{l}\text { Generation of employment } \\
\text { opportunities for tribal }\end{array}$ & $\begin{array}{l}\text { Rs 6,000 crore } \\
\text { Creation of jobs for the tribal and Adivasis }\end{array}$ \\
\hline 6. & Housing sector & $\begin{array}{l}\text { Rs 70,000 crore } \\
\text { Extending the Credit Link Subsidy Scheme (CLSS) }\end{array}$ \\
\hline
\end{tabular}

\section{Interpretation}

1) The provision of free food grains to the migrant workers including noncard-holders in a manner that each person in a family is eligible to obtain $5 \mathrm{~kg}$ wheat/rice and $1 \mathrm{~kg}$ Chana (or any other grain of their choice) for 3 months is a much-needed assistance measure. The Government has started affordable housing for migrant workers and urban poor to ease their livelihood.

2) Interest subvention and infusion of additional working capital funds to farmers will benefit the latter to take additional loans with less interest rates and those who have already taken loans.

3) The interest subvention of $2 \%$ by the Government for those who have availed loans (Rs 50,000 or less) under Mudra Shishu, will be given after the 3-month moratorium Period ends.

4) The move regarding street vendors' credit creation, aims to facilitate the stranded street vendors, the basic necessities of life. Due to the pandemic, people have ceased to go outside for eateries and hence this part of the unorganized sector has been hit badly.

5) The announcement of employment generation for the tribal is more in general terms rather than that pertaining to the covid-19 crisis, which does not provide any immediate relief to the tribal. This will benefit the tribal in the future when the economy has found its normal pace of working.

6) The consumer might get a maximum of 3-4\% interest subvention on housing loans.

\subsection{THIRD TRANCHE - ₹ $1,50,000$ CRORES}

The third tranche of the measures focus on the agriculture including dairy, animal husbandry and fisheries. The Government announced measures and reforms in agricultural regulation and agricultural infrastructure to make it easier for farmers to stockpile and sell crops thereby strengthening the overall agriculture industry. This will be a cluster-based approach, where, local products with high value additions, can reach global markets as per Shri Nirmala Sitharaman. 
Table 3 Third Tranche of the Atma Nirbhar Package

\begin{tabular}{|c|c|c|}
\hline Sl. No & Particulars & $\begin{array}{c}\text { Amount (in Rupees) and } \\
\text { brief }\end{array}$ \\
\hline 1. & Purchases based on & Rs 74300 crores \\
\hline & Minimum Support Prices & $\begin{array}{l}\text { Over } 111 \text { crore litres were procured } \\
\text { extra ensuringpayments of Rs } 4,100 \\
\text { crore. }\end{array}$ \\
\hline 2. & $\begin{array}{l}\text { Fund for setting up of farm } \\
\text { gate infrastructure }\end{array}$ & $\begin{array}{l}\text { Rs } 1 \text { lakh crore } \\
\text { Fund is for enhancing agricultural } \\
\text { infrastructure inthe country. }\end{array}$ \\
\hline 3. & $\begin{array}{l}\text { Formalization of microfood } \\
\text { enterprises }\end{array}$ & $\begin{array}{c}\text { Rs } 10,000 \text { crore } \\
\text { Micro food enterprises to undertake } \\
\text { technical upgradation, meet good food } \\
\text { standards, build brandsand market their } \\
\text { produce. }\end{array}$ \\
\hline 4. & $\begin{array}{c}\text { New Animal Husbandry } \\
\text { Development Fund }\end{array}$ & $\begin{array}{l}\text { Rs 15,000 Crore Supports private } \\
\text { investment in cattle feed } \\
\text { infrastructure, dairy processing, and value } \\
\text { addition. }\end{array}$ \\
\hline 5. & Fishermen & $\begin{array}{l}\text { Rs 20,000 Crore } \\
\text { Aimed at fixing critical gaps in the } \\
\text { fisheries valuechain }\end{array}$ \\
\hline 6. & Herbal Cultivation & $\begin{array}{c}\text { Rs 4,000 Crore } \\
\text { Over } 10 \text { lakh hectares of land will be } \\
\text { covered underherbal cultivation. }\end{array}$ \\
\hline 7. & Beekeeping Initiatives & $\begin{array}{c}\text { Rs } 500 \text { Crore } \\
\text { building integrated beekeeping } \\
\text { development centers and other } \\
\text { infrastructure facilities }\end{array}$ \\
\hline 8. & $\begin{array}{l}\text { Operation Greens } \\
\text { Expanded }\end{array}$ & $\begin{array}{l}\text { For Rs } 500 \text { Crore } 50 \% \text { subsidy on } \\
\text { transportation fromsurplus to } \\
\text { deficient markets, } \\
\text { storage and Warehousing including cold } \\
\text { storages. }\end{array}$ \\
\hline 9. & $\begin{array}{c}\text { Amendments to Essential } \\
\text { Commodities Act }\end{array}$ & $\begin{array}{l}\text { To enable better price realization for } \\
\text { farmers andquality achievement by } \\
\text { setting standards }\end{array}$ \\
\hline 10. & Agriculture Marketing & To provide enough choices to farmers \\
\hline
\end{tabular}




\section{Interpretation}

The agriculture sector has been hit a lot due to covid-19. The kharif and rabi crop yields were beautiful. However, the demand for the agricultural crops fell drastically due to lockdowns. The farmers were unable to transport their produce to the market due to labour constraints and transportation problems, main reason being lockdown. Thus, Government came up with these measures to purchase agricultural produces worth 74,300 crores from different farmers all across the country and gave them interest subvention, loans at concessional rates, early payment of Rs.2000 instalment of PM Kisan fund.

\subsection{FOURTH TRANCHE}

The fourth part is about modernizing India's economy. Shri Nirmala Sitharaman on Saturday, May 16th announced the 4th tranche, targeted towards eight sectors viz., Coal, Minerals, Defense Production, Civil Aviation, Power Distribution, Social Infrastructure, Space and Atomic Energy. These include loosening regulations in the above said sectors and to increase private participation.

\section{Table 4 Table showing the Fourth Tranche of the Atma Nirbhar Package}

\begin{tabular}{|c|c|c|}
\hline Sl. No & Particulars & Amount (in Rupees) and brief \\
\hline 1. & Coal sector & $\begin{array}{l}50,000 \text { crore -Evacuation infrastructure } \\
\text { Commercial mining in the country's coal sector and } \\
\text { removal of Government monopoly in coal mining. }\end{array}$ \\
\hline 2. & Mining sector & $\begin{array}{c}\text { Structural reforms in the mining of minerals } \\
\text { throughauctions }\end{array}$ \\
\hline 3. & Defense production & $\begin{array}{l}\text { FDI limit in defense manufacturing under automatic } \\
\text { route will be hiked from } 49 \% \text { to } 74 \%\end{array}$ \\
\hline 4. & Civil aviation & $\begin{array}{c}\text { Rs } 13,000 \text { crore- for building airports. } \\
\text { Restrictions on the utilization of Indian Air Space } \\
\text { aregoing be eased }\end{array}$ \\
\hline 5. & $\begin{array}{l}\text { Power distribution } \\
\text { sector }\end{array}$ & $\begin{array}{l}\text { Power distribution companies in the union } \\
\text { territories(UT) will be privatized. }\end{array}$ \\
\hline 6. & $\begin{array}{l}\text { Social- } \\
\text { infrastructure } \\
\text { projects }\end{array}$ & $\begin{array}{l}\qquad \text { Rs 8,100 crore } \\
\text { Funding will be done through viability gap funding } \\
\text { (VGF) increasing the quantum by } 10 \text { per cent. }\end{array}$ \\
\hline 7. & Space sector & $\begin{array}{l}\text { Planetary exploration and outer space travel } \\
\text { willbe open to the private sector. }\end{array}$ \\
\hline
\end{tabular}


8.
Establishment of research reactor in the PPP

model for the production of medical isotopes

topromote the welfare of humanity

\section{Interpretation}

1) Earlier coal mining was done only by Public Limited Companies like CIL etc and sold only to firms for power generation as a raw material for steel and cement industry.

2) It involves transfer of technology, participation in joint ventures etc. allowing the FDI limit to $74 \%$ in the production of arms and ammunition of our country is on one hand a boon and on another a sin.

3) It is told that easing up of the restrictions on the utilization of Air Space will bring about 1000 crore revenue to the government.

4) Indian majority power distribution companies (DISCOMS) are stateowned and subsidy driven. The power sector in India is always a lossmaking sector with payment dues of up to $13.4 \mathrm{bn}$ USD.

5) The Government now bears $30 \%$ of the total project cost under the PPP (Public Private Partnership) model as against 20\% prior covid-19, as per the normal norms. This means that the Government is willing to pay $30 \%$ of the cost of project in cash to the private firms who are economically viable but is having financial non-feasibility, under the PPP model.

6) Again, the intervention of the private sector in the space sector paves the way for new investments and development of the sector ensuring healthy competition and world class efficiency.

7) Research reactor is used for the production of radioisotopes that are used in applications such as medical, industrial etc.

\subsection{FIFTH TRANCHE}

The fifth part mainly focuses on reforms related to business regulation, increasing state Government borrowing limits, raising funds for rural workers etc. Shri Nirmala Sitharaman explained seven steps ranging from MNREGA, Health and Education sector to Ease of Doing Business, decriminalization of Companies Act, Public Sector Enterprises- related steps, and State Governments related reforms.

\section{Table 5 Fifth Tranche of the Atma Nirbhar Package}

\begin{tabular}{|c|c|c|}
\hline $\begin{array}{l}\text { Sl. } \\
\text { No }\end{array}$ & Particulars & Amount (in Rupees) and brief \\
\hline 1. & MNREGA Scheme & $\begin{array}{l}\text { Rs } 40,000 \text { crore over and above the budget } \\
\text { estimateAddresses the need for work for } \\
\text { the refugee migrants. }\end{array}$ \\
\hline 2. & Health sector & $\begin{array}{l}\text { Establishment of more hospital blocks and } \\
\text { publichealth labs }\end{array}$ \\
\hline 3. & Education & $\begin{array}{c}\text { Aimed at technology-driven education via } \\
\text { DIKSHA }\end{array}$ \\
\hline
\end{tabular}




\begin{tabular}{|c|c|c|}
\hline 4. & $\begin{array}{l}\text { Insolvency and } \\
\text { bankruptcy code }\end{array}$ & $\begin{array}{c}\text { No fresh insolvency proceedings would be } \\
\text { initiatedfor a year }\end{array}$ \\
\hline 5. & $\begin{array}{l}\text { Decriminalization of the } \\
\text { companies act }\end{array}$ & $\begin{array}{c}\text { The majority of compoundable offences sections } \\
\text { willbe shifted to internal adjudications. }\end{array}$ \\
\hline 6. & Ease of Doing Business & $\begin{array}{c}\text { Allowing companies to list securities } \\
\text { directly inauthenticated foreign } \\
\text { jurisdictions. }\end{array}$ \\
\hline 7. & $\begin{array}{l}\text { Public sector enterprise } \\
\text { policy }\end{array}$ & $\begin{array}{l}\text { Defining strategic sectors which require the } \\
\text { presenceof PSEs. }\end{array}$ \\
\hline 8. & $\begin{array}{l}\text { Support to the state } \\
\text { governments }\end{array}$ & $\begin{array}{l}\text { Increase the borrowing limits of UTs and States } \\
\text { from } 3 \% \text { to } 5 \% .\end{array}$ \\
\hline
\end{tabular}

\section{Interpretation}

1) The MNREGA hike of ₹20 earlier, had increased the wages for individuals in rural areas to meet their domestic needs. Now the further allocation of Rs 40,000 crore over the set budget for the year of Rs 61,000 crore will generate more person days of work and will help the individuals in rural areas to gain access to more cash in hand so that they could use those funds to meet even the medical expenses.

2) The measure on Health Sector by increasing the expenditure on the health infrastructure at the ground level provides relief to people with corona infection.

3) The educational measures have brought about confusion and chaos in the minds of people regarding announcements of reopening of schools, colleges and universities. The education ministry updates information regarding the same at regular intervals but is not firm in its announcements. There has been introduction of e-platform called DIKSHA for the conduct of classes, along with TV broadcasts for Government school-going children from morning till evening, dedicated exclusively for them.

4) The insolvency regulations like the defaults or insolvency during Covid19 do not constitute as defaults and it is debatable as companies tend to take advantage of these situations for the non-repayment of loan.

5) The reforms in the public sector like reduction in the number of public sector units to only one in the place of four, will reduce the administration costs but is also going to pave the way for unemployment.

6) The announcement regarding the borrowing limits for the state governments to have seen an increase from $3 \%$ to $5 \%$ thus by increasing the borrowing amount by 4.28 trillion, has proved unsuccessful as it was found that the states have borrowed only to the tune of $14 \%$ of the limits while the other $86 \%$ remained unutilized. 


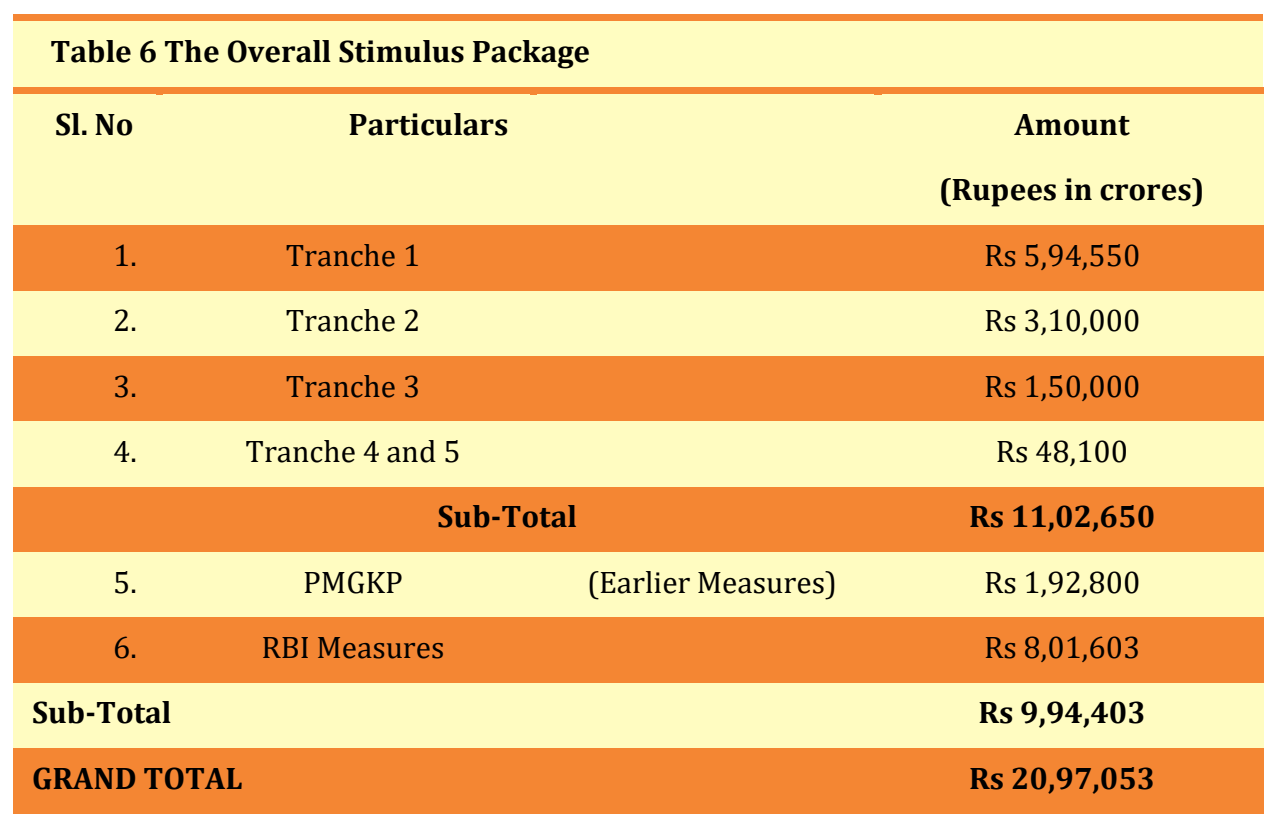

\subsection{ANALYSING INDIA'S MONETARY POLICY}

\section{The measures undertaken under Monetary Policy are as under}

On March 27, 2020, a day after the announcement of PMGKP of 1.7 lakh crore, India's central bank, the Reserve Bank of India (RBI) lowered its repo rate, the bank's benchmark interest rate, by $0.75 \%$ to $4.4 \%$, The Repo Rate was earlier 5.15 . It also lowered the reverse repo rate by $0.9 \%$ to $4 \%$ from $4.9 \%$.

The RBI also announced that the Cash Reserve Ratio (CRR) would be reduced by $100 \mathrm{bps}$, or $1 \%$, and thus reduced to $3 \%$ from the existing $4 \%$. This would be applicable from March 28, and would inject Rs. 1, 37,000 crores.

\section{FINDINGS}

From the above analysis and interpretation, it is found that the Indian economy has suffered a lot due to the corona virus followed lockdowns, seal downs and shut downs of factories and workplaces.

Hence to overcome the drowning Indian economy and to uplift the Indian economy, the Finance Minister, Shri Nirmala Sitharaman announced a 20-lakh crore package called the Atma Nirbhar package which touches upon every segment of the economy. However, it is found from the analysis that the economic stimulus package is indeed beneficial in the long run to make the economy stronger and independent. The package fails to pay a detailed attention to the current crisis as there are very less relief measures stated in the Atma Nirbhar package, but on the other hand, has stated reforms which will fuel the economy in the later stages.

It is also found that nearly $40 \%$ of the package is a contribution by the Central Bank of India to tackle the financial crisis that arose as a result of Covid-19. The remaining $60 \%$ of the 20 -lakh crore relief fund only is being funded by the Central Government.

It is found that the relief measures stated in the package are beneficial to every sector in the economy by a way of creating demand in the economy by boosting each 
and every sector with the help of these reforms and relief measures. However, the relief measures stated in the package do not give any immediate reliefs to the economy.

It is also found that due to workplaces and factories shut down, many have lost jobs and business increasing the unemployment rate. This in turn is a loss for the Government are the Government id unable to collect revenues. Adding to this is the announcement of the economic package of a sum equivalent to $10 \%$ of GDP, a National Expenditure, for which there are merely any returns expected by the Central Government in the short run.

It is found that India is lagging behind in the GDP growth rate as the current year's GDP growth rate is expected to be a meagre figure of $1.6 \%$ as per Goldman Sachs. It is very necessary to increase the GDP growth rate in the following years, which is believed to happen by the Atma Nirbhar package in the way of demand creation.

\section{SUGGESTIONS}

Containing the Covid-19 situation and trying to uplift the Indian economy is no child's play. The Government has taken several measures in this regard to the best of its knowledge in consent with professional economists, finance analysts etc and has fought the battle very bravely so far by taking some bold actions. The GOI by announcing the stimulus package has created an artificial foundation for the survival of the economy as the stimulus package is bound to revive demand in the economy. Here are some suggestions to the Government that would go well with the reforms in the stimulus package and monetary aids, stated earlier, to help uplift the hit Indian economy.

Taxes such as long-term capital gain tax, inheritance tax or the wealth tax, and dividend distribution taxes should be lowered or ceased as these results in demotivation for the companies and individuals to make profit.

The start-ups in India should be encouraged more and more by providing all the support they need in terms of finance, business matters, production, marketing etc, to make India self-reliant.

The country's exports must outshine the imports and have a balanced BOP statement. Overall, the country must reduce its dependency on other countries for products and service.

\section{CONCLUSION}

The package was done in consultation with economists, academicians, exbankers, ex-finance ministry officials and industries, the idea was to make available more liquidity in the economy and revive demand.

The aim was to go through this route of stimulating the economy through companies, institutions, enterprises and businesses- all getting assistance by banks or formulations through which businesses restart. These measures will provide more liquidity in the economy, if there is more liquidity in economy, people will get money in their hands and this will kickstart economy and bring more demand.

Many industries are benefiting from the world pandemic in India and are growing daily. Industries such as information technology, cloud service industry, communications industry, chemical industry, pharmaceuticals, e-commerce platforms, and banking industry by the way of internet and mobile banking are in high demand due to the pandemic-caused lockdowns and social distancing measures. 
India now expects that if it reduces the dependency on other countries for several products, by becoming a self-reliant country. Then the GDP will gradually increase over the years and has an estimate of GDP growth rate of $6.0 \%$ in 2021 as per IMF estimations.

\section{REFERENCES}

Anuragh Balajee, S. T. (2020), (April 20). Fiscal situation of India in the time of covid19, retrieved from https://doi.org/10.2139/ssrn.3571103

Dr. M. Murugeswari, A. D. (2020), (may 21). Impact of coronavirus (Covid 19) on Indian Economy: An overview, pp.424-427

Goodell, J. W. (2020), (July 20). Covid-19 and finance: agendas for future research. Finance Research Letters. retrieved from https://doi.org/10.1016/j.frl.2020.101512

Goyal, A. (2020), Post covid-19: recovering and sustaining India's growth. Mumbai: Indira Gandhi institute of development research. retrieved from https://doi.org/10.1007/s41775-020-00089-z

Meghana Mishra, P.M. (2020). Prioritizing financial crises. International journal of system dynamics applications. retrieved from https://www.igiglobal.com/article/prioritizing-financial-crises-due-to-covid-19/255840

Mohan, D. (2020), (March 14). What will be the economic consequences of covid19 for India and the world? retrieved from http://dspace.jgu.edu.in:8080/jspui/bitstream/10739/3375/1/What\%20 Will\%20Be\%20the\%20Economic\%20Consequences\%20of\%20COVID\%20 19\%20for\%20India\%20and\%20the\%20World.pdf

Mythili. (2020). Covid-19 impact on SMEs and recovery measures to be taken for overcoming economy crisis in India.

Raney, H. M. (2020), (march) covid 19 pandemic: impact on MSMEs. Studies in Indian place names (UGC CARE Journal), pp. 396-401.

Raut, P. C. (2020). A study of Indian economy during covid-19 pandemic. UGC CARE journal, 363-366.

Selvan, D. A. (2020). Impact of covid-19 on the Indian banking sector. UGC CARE Journal, 129-133.

Sengupta, S. M. (2020). Covid-19: impact on the Indian economy. Mumbai: Google scholar.

Varma, R. P. (2020), (April 4), Covid 19-indian scenario, challenges and possible revival strategies. 